\title{
THE EFFECT OF THE SURROUNDING ENVIRONMENTAL TEMPERATURE ON CARDIAC PROPERTIES OF NORMAL INDIVIDUALS
}

Ragab, M. H. ${ }^{(1)}$; Mohammed, A. S. ${ }^{(2)}$ and Al- Sayed, Marwa, N. ${ }^{(1)}$

1) Institute of Environmental Studies and Research, Ain Shams University. 2) National Heart Institute.

\begin{abstract}
Cardiovascular disease is the most prominent circulation disorder around the world and one of the leading cause of disease burden in developing countries as the three fourth of the global deaths due to coronary heart disease occur in the middle income countries. Extreme cold episodes significantly has its impact on health ,especially on the cardiovascular system by different mechanisms. This is a community based study aimed to detect the influence of the surrounding environmental temperature on cardiac function. Apparent healthy individuals submitted for longitudinal study along winter and Summer seasons.

All subjects undergo specified inclusion and exclusion criteria.

All subjects will be exposed to the following investigations at one of the coldest day in Winter (below $14^{\circ} \mathrm{C}$ ) and one the hottest day in Summer (above $34^{\circ} \mathrm{C}$ ):

-measurement of arterial blood pressure.

-local examination of heart.

-recording electrocardiograph ( ECG).

Results of the present study show significant elevation in the blood pressure, associated with cold weather.On the other hand there were no- significant changes in the heart rate or other ECG findings.

From our results we can conclude that apparently healthy individuals display adaptive functional changes in the cardiovascular system during seasonal variation. Cold weather is
\end{abstract}


J. Environ. Sci.

Institute of Environmental Studies and Research - Ain Shams University

associated with slight increase in thearterial blood pressure (systolic and diastolic).

Key Words: Environmental Temperature - Cardiac Properties Blood Pressure - Electrocardiograph.

\section{INTRODUCTION}

Various diseases and disorders such as heat stroke and hypothermia linked with temperature extremes . furthermore ,the results of a number of investigations suggests that the relation between mortality and ambient temperature appears graphically as " $\mathrm{U}$ " or "V" shape with mortality rate lower on days in which the average temperature range between $15^{\circ} \mathrm{C}$ to $25^{\circ} \mathrm{C}$, rising progressively as the ambient temperature becomes hotter or colder. Zanobetti, et al, 2015.

Major predicted health effects of long term climatic change include skin and eye damage from increased exposure to ultraviolet radiation ,increased incidence of respiratory and cardiovascular diseases ,increased incidence of vector - borne and water-born diseases , and heat related morbidity and mortality.Semenza,et al ,1996.

Cardiovascular diseases are the most prominent circulation around the world ,some causes roughly 1.2 million heart attack each year and $40 \%$ of those suffering heart attacks will die .Xiaelunsun, et al, 2012.

Many personal and environmental factors may modify the effects of atmospheric temperature on human health, including age , gender ,presence of chronic disease ,economic ,demographic , factors, access to air conditioning and availability of health care survicesGrize ,et $a l, 2005$. 
Previous studies have reported that elderly and women are more vulnerable to extreme temperatures than the young and men ,respectivelyHuyne, et al, 2001; Kysely,et al,2009. People with cardiovascular or respiratory diseases are more susceptible to adverse effects of extreme temperatures than healthy people.Miron ,et al,2012; Keating ,et al,1997 ;McGregor,et al,2004.

A population study has shown that cardiovascular symptoms ,such as arrhythmias and chest pain are experienced in the cold by $4 \%$ of the general population. Ratikka, et al,2002.

The general tendency of blood pressure (casual and ambulatory measures) in Winter than in Summer.Kristal,et al ,1994.

A strong association has been reported between seasonal changes and blood pressure. Kristal,et al ,1996.

Because of the projected consequences of global warming and the increased frequency and intenisty of heat waves ,heat related mortality may achieve greater public health significance during the coming decades.Meehl ,et al,2001.

The cardiac properties is determined by evaluation of:

-Cardiac Rhythmisity: in healthy individuals breathing at a normal, the heart rate varies with the phases of respiration : it accelerate during inspiration, and decelerate during expiration.MaW, et al,2013.

-Cardiac contractility: which is defined by the ability of heart to contracts and depends on the concentration of the intracellular calcium. As the concentration of the intracellular calcium increases the contractility increases.Kysely, et al,2011. 
J. Environ. Sci.

Institute of Environmental Studies and Research - Ain Shams University

-Cardiac Conductivity: the electrical activity is spontaneously generated

by the SA node, the conduction of the electrical impulse can be recorded on the ECG strip .

-Heart Rate: which refers to the speed of the heart beat. It is normally ranges from 60 to 100 beat per minute (b/m). Huynen,2001.

\section{AIM OF THE WORK}

To detect the influence of surrounding environmental temperature on cardiac function.

\section{SUBJECTS AND METHODS}

This is a community based study.subjects are apparently healthy individuals submitted for longitudinal study along Summer and Winter seasons. Subjects were submitted to examination by two settings :

At one of the coldest day in Winter (below $14^{\circ} \mathrm{C}$ ) and the other setting done at one of the hottest day in Summer $\left(34^{\circ} \mathrm{C}\right)$. Every subject is followed up at the following parameters:

\section{-Inclusion Criteria :}

All volunteers are male (to avoid hormonal and menstrual influence), age ranging from twenty to forty years old (as the mature age which is not affected by the growth stages at early ages ,and deterioration of metabolic rate due to aging).

\section{-Exclusion Criteria:}

Comprehensive medical history and examination is carried out to exclude those with all apparent known pathological condition.

All subjects were exposed to the following investigations: 
1-Measurement of arterial blood pressure to detect systole, diastole and mean arterial blood pressure.

2-Local examination of heart to detect heart sounds.

3-Recording of Electrocardiograph (ECG) to evaluate AV conduction, ischemic changes, $\mathrm{ST}$ segment changes, $\mathrm{T}$ wave changes, QRS complex ,pathological Q.

All ECG's strips were scanned using a personal computer at a resolution 1200 dpi (dot per inch). Then a special graphic program was used to measure the ECG parameters, as all waves and intervals were measured digitally using the PC. The start and the end of the wave is well defined (to avoid errors in measurement).

We chose lead 2 to illustrate the ECG findings as it reflects the normal spread of the excitatory wave from the upper right (SA node) to the lower left .which was preferable as almost all waves were well defined in this lead.

Comprehensive paired data of the individuals are calculated to evaluate any significant changes in cardiac properties under the environmental temperature changes. 
J. Environ. Sci.

Institute of Environmental Studies and Research - Ain Shams University

\section{STATISTICAL ANALYSIS \\ RESULTS}

This study was performed on (30) male adult volunteers, age ranging between twenty to forty years old.

We have two readings for each parameter. The data were taken twice a year (in one of the coldest day in Winter and in one of the hottest day in Summer ,independent sample t- test was used to compare data in the two settings Winter and Summer ,data are expressed as means, statistical significance was taken $\mathrm{P}<0.05$ for all measurements. Which is illustrated as following:

The mean arterial blood pressure (MAP) was calculated for each case :

$$
\text { Mean BP }=\frac{\text { Systolic BP }+(2 \times \text { Diastolic BP })}{3}
$$

\section{Ven Bergen ,et al ,1954.}

then all readings was statistically analyzed, and the mean of the (MAP) recorded in Winter and Summer .

Table (1): Comparison between mean of the blood pressure in winter and Summer

\begin{tabular}{||c|c|c|c|c|c||}
\hline \multirow{2}{*}{$\begin{array}{c}\text { Blood } \\
\text { Pressure }\end{array}$} & Season & Mean & $\begin{array}{c}\text { Std. } \\
\text { Deviation }\end{array}$ & $\begin{array}{c}\text { Independent } \\
\text { sample t-test }\end{array}$ & P-value \\
\cline { 2 - 6 } & Winter & 88.8370 & 6.40368 & 2.719 & $0.009 * *$ \\
\cline { 2 - 4 } & Summer & 83.0404 & 7.97079 & 2.79 & \\
\hline
\end{tabular}

(**) Highly statistically significant at $P<0.01$

Table (1) shows highly statistically significant difference between winter and summer.in Winter was $88.8370 \mathrm{mmHg}$ reduced in Summer 
to $83.0404 \mathrm{mmHg}$. The standard deviation (Std deviation) for winter was 6.40368 and for Summer was 7.97079By using the independent sample t- test the P-value was 0.009 , as $\mathrm{P}<.0 .01$, So the difference was highly statistically significant. See table (1) and plotted in figure(1)..

Table (2): Comparison between Systolic B.P in summer and winter

\begin{tabular}{|c|c|c|c|c|c|}
\hline \multirow{3}{*}{ Systolic B.P } & Season & Mean & $\begin{array}{c}\text { Std. } \\
\text { Deviation }\end{array}$ & $\begin{array}{c}\text { Independent } \\
\text { sample t-test }\end{array}$ & P-value \\
\cline { 2 - 6 } & Winter & 118.2609 & 11.14050 & 2.766 & $0.008^{* *}$ \\
\cline { 2 - 6 } & Summer & 109.1304 & 11.24643 & 26 & 0.06 \\
\hline
\end{tabular}

(**) Highly Statistically Significant at $P<0.01$

Table (2) shows highly statistically significant difference between winter and summer.the mean of systolic blood pressure in winter was $118.2609 \mathrm{mmHg}$ reduced in summer to $109.1304 \mathrm{mmHg}$. The Std deviation for Winter was 11.14050 and for Summer was 11.24643. The $\mathrm{P}$ value was 0.008 which is highly significant as $\mathrm{P}<.01$. seen in table(2) and plotted in figure (2).

Table (3): Comparison between Diastolic B.P in summer and winter

\begin{tabular}{|c|c|c|c|c|c|}
\hline \multirow{2}{*}{ Diastolic B.P } & Season & Mean & $\begin{array}{c}\text { Std. } \\
\text { Deviation }\end{array}$ & $\begin{array}{c}\text { Independent } \\
\text { sample t-test }\end{array}$ & P-value \\
\cline { 2 - 6 } & Winter & 73.9130 & 6.56376 & 2.065 & $0.045^{*}$ \\
\cline { 2 - 6 } & Summer & 69.5652 & 7.67420 & 205 & \\
\hline
\end{tabular}

(*) Statistically Significant at $P<0.05$

table (3) shows statistically significant difference between winter and summer.Table (3) shows that the mean diastolic blood pressure in winter was $73.9130 \mathrm{mmHg}$ reduced in summer to $69.5652 \mathrm{mmHg}$. the Std deviation for Winter was 6.56376 and for Summer was 7.67420 .The calculated P-value equals .045 which is statistically significant . plotted on figure (3). 
J. Environ. Sci.

Institute of Environmental Studies and Research - Ain Shams University

Statistical analysis of the ECGs:

ECG was recorded twice ( in Winter and Summer) and the electrocardiographic findings was determined and compared between winter and summer, data analyzed statistically and expressed as means, Std deviation and the independent sample t- test was used ,statistical significance was $\mathrm{P}<0.05$ for all measurements.

Table (4): Comparison between P-wave Amplitude inwinter and summer

\begin{tabular}{|c|c|c|c|c|c||}
\hline \multirow{2}{*}{$\begin{array}{c}\text { P-wave } \\
\text { Amplitude }\end{array}$} & Season & Mean & $\begin{array}{c}\text { Std. } \\
\text { Deviation }\end{array}$ & $\begin{array}{c}\text { Independent } \\
\text { sample t-test }\end{array}$ & P-value \\
\cline { 2 - 5 } & Winter & .14707 & .045409 & \multirow{2}{*}{0.776} & \multirow{2}{*}{0.443} \\
\cline { 2 - 5 } & Summer & .15750 & .039440 & & \\
\hline
\end{tabular}

Table (4) shows that the mean of the P-wave amplitude in Winter was .14707 and in Summer was 0.15750 the calculated Std deviation in Winter was 0.045409 and for Summer was 0.039440 . The independent sample t-test gives insignificant $\mathrm{P}$ - value equal 0.443 in which $\mathrm{P}>0,05$.

Table (5): Comparison between P-wave Duration in winter and summer

\begin{tabular}{|c|c|c|c|c|c||}
\hline \multirow{3}{*}{$\begin{array}{c}\text { P-wave } \\
\text { Duration }\end{array}$} & Season & Mean & $\begin{array}{c}\text { Std. } \\
\text { Deviation }\end{array}$ & $\begin{array}{c}\text { Independent } \\
\text { sample t-test }\end{array}$ & P-value \\
\cline { 2 - 6 } & Winter & .09550 & .019403 & 0.896 & 0.376 \\
\cline { 2 - 4 } & Summer & .10125 & .021105 & 0.896 & 0.376 \\
\hline
\end{tabular}

Table (5) shows that the mean of the $\mathrm{P}$-wave duration in winter was $0.09550 \mathrm{sec}$ and increased in summer to $0.10125 \mathrm{sec}$, and the Std deviation for Winter was 0.019403 and for Summer was 0.10125 . by the use of the independent t-test and calculation of the P-value equal 0.376 in which $\mathrm{P}>0.05$ it shows insignificant difference . 
The non significant change in the P-wave amplitude and duration between Winter and Summer indicates no change in the atrial systole.

Table (6): Comparison between P R Interval in summer and winter

\begin{tabular}{|c|c|c|c|c|c|}
\hline \multirow{3}{*}{ P R Interval } & Season & Mean & $\begin{array}{c}\text { Std. } \\
\text { Deviation }\end{array}$ & $\begin{array}{c}\text { Independent } \\
\text { sample t-test }\end{array}$ & P-value \\
\cline { 2 - 5 } & Winter & .15235 & .028057 & 1.087 & \multirow{2}{*}{0.284} \\
\cline { 2 - 4 } & Summer & .16145 & .024797 & 1.087 & 0.284 \\
\hline
\end{tabular}

Table (6) shows that the mean of the PR interval recorded in Winter was $0.15235 \mathrm{sec}$ raised in Summer in to $0.16145 \mathrm{sec}$. the Std deviation for Winter was 0.028057 and for Summer was 0.024797 . the independent sample t-test used and the P- wave calculated equal 0.284 shows insignificant value as $\mathrm{P}>0.05$.

Which indicates that there is no change in the atrioventricular conduction between Winter and Summer.

Table (7) : Comparison between QRS Complex Duration in winter and summer

\begin{tabular}{|c|c|c|c|c|c|}
\hline \multirow{2}{*}{$\begin{array}{c}\text { QRS Complex } \\
\text { Duration }\end{array}$} & Season & Mean & $\begin{array}{c}\text { Std. } \\
\text { Deviation }\end{array}$ & $\begin{array}{c}\text { Independent } \\
\text { sample t-test }\end{array}$ & P-value \\
\cline { 2 - 6 } & Winter & .0932 & .01977 & -0.459 & 0.649 \\
\cline { 2 - 4 } & Summer & .0958 & .01526 & 0.459 & 0.649 \\
\hline
\end{tabular}

By comparing the QRS complex duration the mean duration in winter was $0.0932 \mathrm{sec}$ elevated in summer to $0.0958 \mathrm{sec}$. the Std deviation for Winter was 0.01977 and for Summer was 0.01526 . but it shows no significant change as the calculated $P$ value was 0.649 which is more than 0.05 . see above in table (7). Which indicates no change in the ventricular systole. 
J. Environ. Sci.

Institute of Environmental Studies and Research - Ain Shams University

Table (8): Comparison between T- wave Amplitude in winter and summer

\begin{tabular}{|c|c|c|c|c|c||}
\hline T-wave amplitude & Season & Mean & $\begin{array}{c}\text { Std. } \\
\text { Deviation }\end{array}$ & $\begin{array}{c}\text { Independent } \\
\text { sample t-test }\end{array}$ & P-value \\
\hline \hline \multirow{2}{*}{ T-waveamplitude } & Winter & .317600 & .1318725 & 0.092 & 0.927 \\
\cline { 2 - 6 } & Summer & .313850 & .1251951 & 0.092 & 0.00 \\
\hline
\end{tabular}

The mean of the T- wave amplitude in winter was $0.317600 \mathrm{mv}$ decreased in summer to 0.313850 mv.but by calculating the $\mathrm{P}$ was 0.927 , the Std deviation in Winter was 0.317600and in Summer waso.313850,by calculating the P-value was0.927 which shows insignificant change between winter and summer as $\mathrm{P}>0.05$.see above table (8) .

Table (9): Comparison between $\mathrm{T}$-wave Duration in summer and winter

\begin{tabular}{||c|c|c|c|c|c||}
\hline $\begin{array}{l}\text { T-wave } \\
\text { Duration }\end{array}$ & Season & Mean & Std. Deviation & $\begin{array}{c}\text { Independent } \\
\text { sample t-test }\end{array}$ & P-value \\
\hline \hline $\begin{array}{c}\text { T-wave } \\
\text { Duration }\end{array}$ & Winter & .16405 & .039055 & 0.740 & 0.464 \\
\cline { 2 - 6 } & Summer & .17210 & .029001 & 0.70 \\
\hline
\end{tabular}

Table (9) shows that the mean of the $\mathrm{T}$-wave duration recorded in winter was $0.16405 \mathrm{sec}$ and prolonged in summer to $0.17210 \mathrm{sec}$. the Std deviation for Winter was 0.039055 and for Summer was 0.029001 . But by calculating the $\mathrm{P}$-value it shows insignificant change $\mathrm{P}$ was 0.464 , in which $\mathrm{P}>0.05$.

As there is no significant difference in $\mathrm{T}$-wave amplitude and duration which indicates no change in the diastole between Winter and Summer. 
Table (10): Comparison between QT Interval in summer and winter

\begin{tabular}{|c|c|c|c|c|c|}
\hline \multirow{4}{*}{ QT Interval } & Season & Mean & $\begin{array}{c}\text { Std. } \\
\text { Deviation }\end{array}$ & $\begin{array}{c}\text { Independent } \\
\text { sample t-test }\end{array}$ & P-value \\
\cline { 2 - 6 } & Winter & .3591 & .02284 & -0.468 & 0.643 \\
\cline { 2 - 4 } & Summer & .3629 & .02856 & 0.643 \\
\hline
\end{tabular}

The mean of the measured QT interval in Winter was $0.3591 \mathrm{sec}$ increased to $0.3629 \mathrm{sec}$ in Summer . the Std deviation in Winter was 0.02284 and in Summer was 0.02856 . by using the independent sample t-test the calculated $\mathrm{P}$ was 0.643 which shows insignificant value as $\mathrm{P}>$ 0.05.see table(10).

Normal isoelectric ST-segment in both Winter and Summer.No pathological Q was detected in Winter and Summer.

Table (11): Comparison between RR- Interval in winter and summer

\begin{tabular}{|c|c|c|c|c|c|c|}
\hline \multirow{3}{*}{ RR- Interval } & Season & Mean & HR & $\begin{array}{c}\text { Std. } \\
\text { Deviation }\end{array}$ & $\begin{array}{c}\text { Independent } \\
\text { sample t-test }\end{array}$ & P-value \\
\cline { 2 - 5 } & Winter & .7986 & 75.94 & .14197 & \multirow{2}{*}{.053} & 0.958 \\
\cline { 2 - 5 } & Summer & .8012 & 75 & .11144 & .053 & \\
\hline
\end{tabular}

The mean of the RR interval in winter was.7986 sec raised to.8012sec in summer, the Std deviation of Winter measurements was.14197and for Summer measurements was 0.11144but by calculating $\mathrm{P}$-value $=0.958, \mathrm{P}>0.05$ indicates insignificant difference between winter and summer (ie no significant change in heart rate HR $75.94 \mathrm{~b} / \mathrm{s}$ to $75 \mathrm{~b} / \mathrm{s})$. See table (11).

The higher T-wave amplitude and shorter duration in Winter may signify non significant decrease in RR interval (ie.non significant Increase in HR) indicates shorter diastolic period in Winter. 
J. Environ. Sci.

Institute of Environmental Studies and Research - Ain Shams University

\section{DISCUSSION}

Results of our present study revealed that change in the surrounding environmental temperature induces change in thearterterial blood pressure, as mentioned in previous studies that the seasonal changeassociated with variation in the environmental temperature induces change in the arterial blood pressure by specific mechanism.Vuori 1987.

Cardiac load is higher in the cold due to cooling induced vasoconstriction, which increases the peripheral resistance and central blood volume further more cardiac filling pressure and volume, and stroke volume areincreased.Vuori,et al,1987.

Both systolic (SBP) and diastolic blood pressure (DBP) were greatest during winterWoodhouse, et al,1993.

Our study applied on apparently healthy individual and the blood pressure was measured twice showing variation between winter and summer readings, rise in the winter reading was recorded .A study by Pietro,et al ,2005applied on hypertensive out patients to determine weather -related changes in 24-hours blood pressure profile. Mean daytime systolic and diastolic arterial blood pressure values were significantly higher during the cold days and significantly lower during the hot days when compared with those obtained during days with intermediate temperature. $(\mathrm{P}<0.05)$.

As well as our study there were no significant change in the heart rate as there is no significant relationship between air temperature and heart rate. 
A study by Muza, et al,1988 on a group of males who showed increased blood pressure during the first cold water exposure, but not during the last cold water immersion. These observations can be explained by the short intermittent adaptation. And by Radomski, et al ,1982 who observed that non pre-adapted healthy volunteers showed significant increased nor epinephrine excretion in urine when suddenly exposed to cold. Physical training and repeated exposure to severe cold may reduce the sympathetic response against cold.

On the other hand our study was applied also on healthy volunteers exposed to cold weather in winter and hot weather in summer. Increased mean arterial blood pressure and systolic blood pressure was recorded.

A seasonal variation in nor-epinephrine and epinephrine execreation has also been reported in men, higher levels being found in winter. Suggesting an increase in the activity of the sympathoadrenal system.Leblanc, et al, 1979.

These results was explained by Hiramatsu,et al,1984 that the stimulation of cold receptors of the skin ,particularly, induces stimulation of the sympathetic nervous system, as indicated by increased levels of catecholamine in blood .

No significant difference in the ECG findings, In previous study recorded changes in the human ECGs in case of incidence with Hypothermia,these changes include slowing of the pulse rate and prolongation of thePR and QTc intervals. Reynolds ,et al, 1965.By reviewing the methodology of this study we found that it differs from 
J. Environ. Sci.

Institute of Environmental Studies and Research - Ain Shams University

our study as it is applied on hypothermic patients i.e. the relation between body temperature and ECGs changes but our study is applied on apparently healthy, norm thermic subjects as we study the relation between environmental temperature and the ECG changes referred to changes in the cardiac properties.

The residents of cold region display adaptive functional changes in their cardiovascular systems. Mochalova, 1970.

Another study that determine analysis of the ECGs of healthy man residents of north Europe of different age groups.An increase in the Pwave amplitude recorded in leads II ,avl ,V4.. Macfarlane ,et al,1989.QRS complex didn't differ from the corresponding middle latitude region.

$\mathrm{T}$ wave amplitude was higher than the normal values. Ashely,et $a l, 2000$.but the ST segment didn't exceed the normal limit. Varlamova ,et al,.2002.

This study differs from our study asit compare between the ECGs of different groups of people living in different geographical areas (cold and warm region) and comparing the age related changes in ECGs parameters. Varlamova ,et al,.2002 our study compare the ECGs parameters of the same group of people at different environmental temperature. 


\section{CONCLUSION}

Both systolic (SBP) and diastolic blood pressure (DBP) were greatest during the winter.

Nosignificant change was recorded in the ECG findings, or in other cardiac properties.Indoor and outdoor (surrounding)temperature have independent effects on systolic and diastolic blood pressure, and both should be controlled for studies that measure blood pressure. Improved protection against cold temperatures is very important.

The public health implications of these findings deserve further investigations.

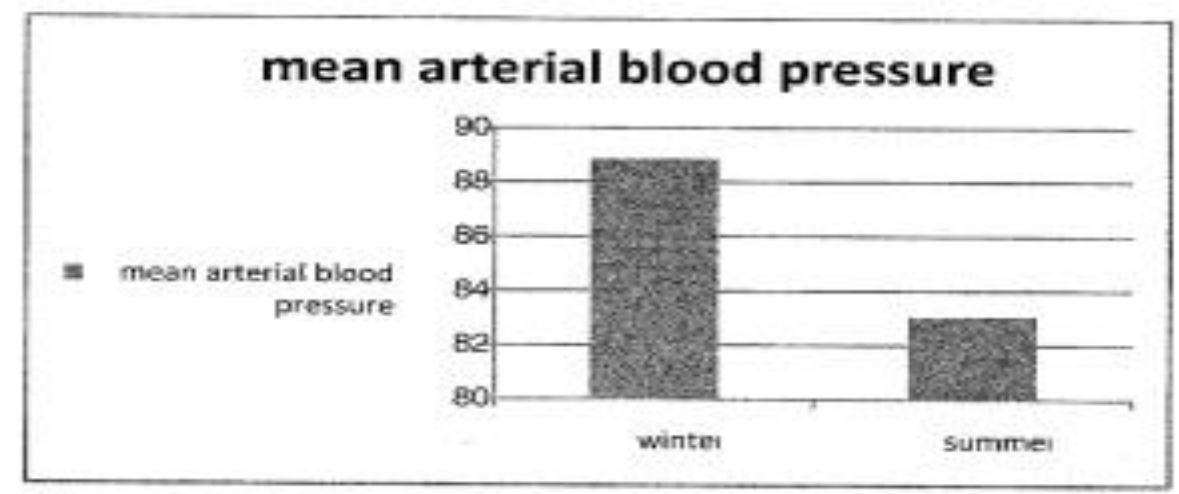

Figure(1): comparison between mean arterial bloodpressure in winter and summer 
J. Environ. Sci.

Institute of Environmental Studies and Research - Ain Shams University

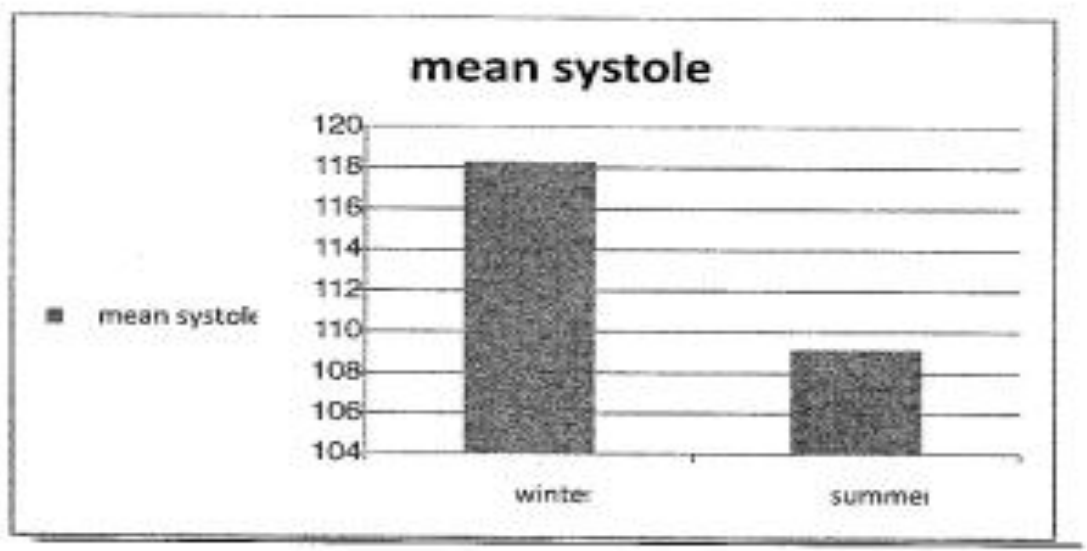

Figure(2): comparison beteen systolic blood pressure in winter and summer

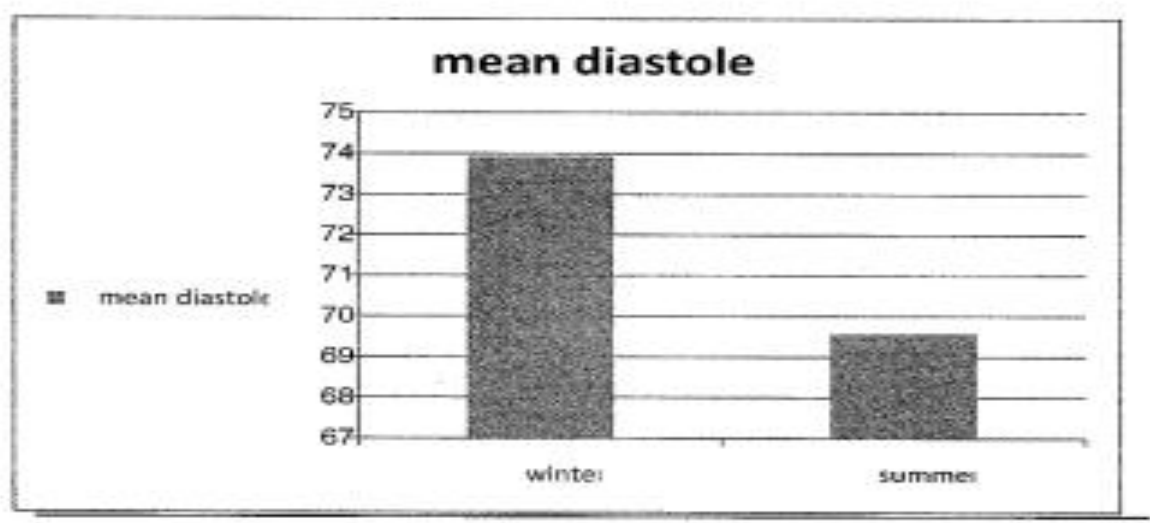

Figure(3): comparison between diastolic blood pressure in winter and summer 


\section{REFERENCE}

Antonella , Zanobetti and Annette Peters.(2015): Disentangling interactions between atmospheric pollution and weather. $\mathbf{J}$ Epidemiol Community Health; 69(7): 613-615.

Ashley EA, Raxwal VK and Froelicher VF (2000): The prevalence and prognostic significance of electrocardiographic abnormalities.J Cardiol;25 :1-72.

Grize L, Huss A, Thommen O, Schindler $\mathrm{C}$ and Braun-Fabrlander C(2005): Heat wave 2003 and mortality in Switzerland. J Swiss Med Wkly, 135:200-205.

Huynen M, Martens P, Schram D, Weijenberg MP and Kunst AE(2001): The impact of heat waves and cold spells on mortality rates in the Dutch population. J Environ Health Perspect 109:463-470.

Keatinge WR, Donaldson GC, Bucher K, Cordioli E, Dardanoni L, Jendritzky G, Katsouyanni K, Kunst AE, Mackenbach JP, Martinelli M, McDonald C, Nyh S and Vuori I (1997): Cold exposure and winter mortality from ischaemic heart disease, cerebrovascular disease, respiratory disease, and all causes in warm and cold regions of Europe. J Lancet, 349:13411346.

Kristal -Boneh E, Harari G, Green MS and Ribak J(1996):Body Mass index is associated with differential seasonal change in ambulatory blood pressure. J Hypertensions 9(12):1179-1185.

Kristal-Boneh E, Schwartz K, HarariG,Ribak and GreenMS(1994) : Seasonal variation in 24-h ambulatory blood pressure .Ambulatory monit ; 7:154 .

Kyselý J, Plavcová E, Davídkovová H, Kynč 1 J(2011): Comparison of hot and cold spell effects on cardiovascular mortality in individual population groups in the Czech Republic. JClimate Res , 49:113-129. 
J. Environ. Sci.

Institute of Environmental Studies and Research - Ain Shams University

Kyselý J, Pokorná L, Kynč 1 J, Kř íž B.(2009): Excess cardiovascular mortality associated with cold spells in the Czech Republic. BMC Public Health , 9:19.

Lablanc J,Cote J ,Jobin M \&Labrie D(1979):Plasma catecholamines and cardiovascular responses to cold and mental activity . J App Physiol ;47:1207-11.

Macfarlane, P.W. and Lawrie. (1989): Comprehensive Electrocardiology, Theory and Practice in Health and Disease , T.D.V., Eds. Pergamon, New York . 3: 14411442.

Martens P, Schram D, Weijenberg MP and Kunst AE (2001): The impact of heat waves and cold spells on mortality rates in the Dutch population. Environ Health Perspect. 109: 463470.

Ma W, Yang C, Chu C, Li T, Tan J and Kan H(2013): The impact of the 2008 cold spell on mortality in Shanghai, China. Int J Biometeorol. 57:179-184.

McGregor GR, Watkin HA and Cox M (2004): Relationships between the seasonality of temperature and ischaemic heart disease mortality: implications for climate based health forecasting. Climate Res. 25:253-263.

Meehl GA , Zwiers F and Evans J.(2001): Trends in extreme weather and climate events: issues related to modeling extremes in projections of future climate change .J American Metriological Society. 81:427-36.

Miron IJ, Montero JC, Criado-Alvarez JJ , Linares C and Diaz J(2012): Intense cold and mortality in Castile-La Mancha (Spain): study of mortality trigger thresholds from 1975 to 2003.Int J Biometeorol , 56:145-152.

Mochalova M.I. (1970): The Hemodynamic Parameters during the Human Acclimatization in the Far North, Severe (Human Acclimatization and the Regional Pathology in the North), J Arkhangel'sk ;21:120. 
Muza SR ,Young AJ , Sawaka MN, Bogart JE and Pandolf KB (1988): Respiratory and cardiovascular responses to cold stress following repeated cold water immersion. Undersea Biomed Res ; 15:78-165.

PietroAmedoModesti ,MarcoMorabito, IcopoBertolozzi, Luciano Massetti, Gabriele Panci, Camilla Lumachi, AlessiaGiglio, GrzegorzBilo ,GianlocaCaldara ,Laura Lonati ,Simone Orlandini ,GiampieroMaracchi ,GiueppeManicia ,Gian FrancoGensini and GianfrancoParati,(2006):Weather Related Changes in 24-Hour Blood Pressure Profile. J Refdoc.fr; 47:155-161.

Radomski MW and Boutelier C(1982):Hormone of normal and intermittent cold-preadapted human to continuous cold . J App Physiol ;53:16-610.

Ratikka VP, RytkonenM ,Nayha S and Hassi J(2007): Prevalence of cold related complaints, symptoms and injuries in the general population. Int J Biometeorol ;51(5):441-8. .

Reynolds A., MD; Francis L. Van Veen, MD. ( 1965): Electrocardiographic Changes in Accidental Hypothermia JAMA; 193(2):161-163.

Semenza JC, Rubin CH, Falter KH, Selanikio JD, Flanders WD, Howe HL and Wilhelm JL (1996): Heat-related deaths during the July 1995 heat wave in Chicago.NEngl J Med , 335:84-90.

Varlamova N.G. and Evdokimov V.G.,(2002):Changes in Electrocardiographic Parameters in Males of the European North as Markers of Climate - and Age -Related Effects, Institute of Physiology,Komi Research Center ,Ural Division ,Russian Academy of sciences ,Syktyvkar ,Russia. J Human Physiology ;28(6):737-742,

Ven Bergen FH, Buckely JJ \& French LA (1954): Comparison of indirect and direct methods of measuring arterial blood pressure. J Circulation. 10:481-90.

Vuori (1987): The heart and the cold. J Ann Clin Res. 19:156-62. 
Seasonal variation of blood pressure and its relationship to ambient temperature in an elderly population. J Hypertension. 11 (11): 1267- 1274.

Xiaelunsun, Shu,Yiliao,Wei, Chun, Tseng, PinYu, Wei and Min Wu(2012): Cardiovascular Disease .J Cardiovascular Disease and research. 3( 4 ): 251-254.

\section{تأثير برارة البيئة المفيطة على الخمائس القلبية على الاشخاص الطبيعيين}

$[\wedge]$

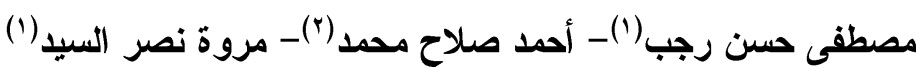

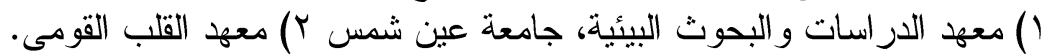

\section{المستخلص}

أمر اض القلب و الاوعية الدموية هى الاضطر اب الابرز والاكثر شيوعا حول العـالم.

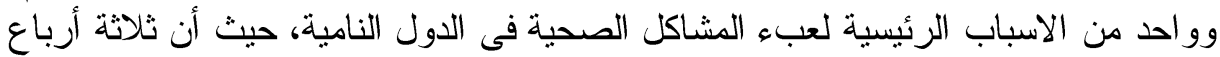

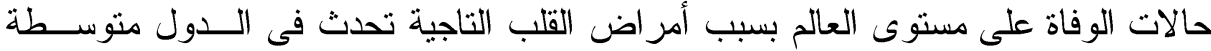

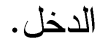

نجد ان فترات البرودة القصوى لها تأثير ملحوظ على الصحة وخاصة الجهاز الدورى

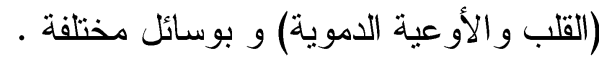

هذه الدراسة هى دراسة مجتمعية تهدف للكثيف عن تاثير درجة حرارة البيئة المحيطة على الوظائف القلبية

حيث يخضع أفراد أصحاء ظاهريا لدراسة طولية على مدار فصلى الشتاء و الصيف.

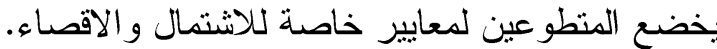

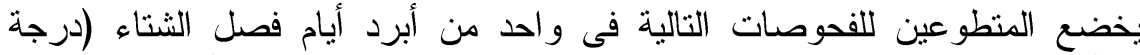

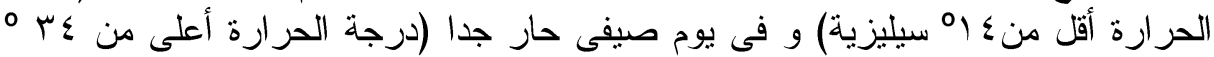

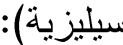

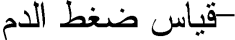

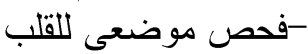

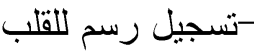




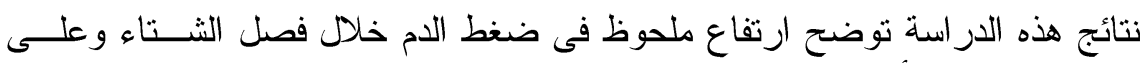

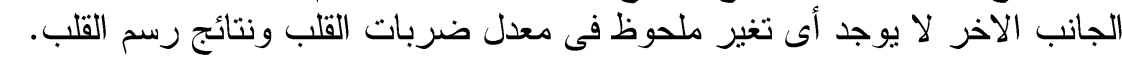

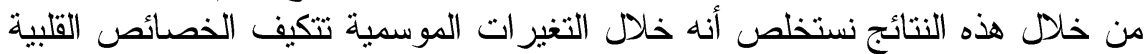

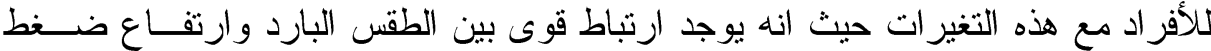
الدم(الانبساطى و الانقباضى). 